\title{
Penicillin disrupts mitochondrial function and induces autophagy in colorectal cancer cell lines
}

\author{
FEI HU ${ }^{1,2}$, YU WU ${ }^{1}$, CHENG LIU ${ }^{1}$, YINGCHAO ZHU ${ }^{1}$, SHAZHOU YE ${ }^{1}$, \\ YANG XI ${ }^{1}$, WEI CUI ${ }^{3}$ and SHIZHONG BU ${ }^{1}$ \\ ${ }^{1}$ Diabetes Research Center, School of Medicine, Ningbo University, Ningbo, Zhejiang 315211; \\ ${ }^{2}$ Cixi Biomedical Research Institute, Wenzhou Medical University, Cixi, Zhejiang 315300; \\ ${ }^{3}$ Department of Colorectal Surgery, Ningbo Medical Center Lihuili Hospital, Ningbo, Zhejiang 315211, P.R. China
}

Received October 10, 2020; Accepted July 9, 2021

DOI: 10.3892/ol.2021.12952

\begin{abstract}
Colorectal cancer is a common malignant tumor of the gastrointestinal tract. Currently, the main treatment is surgical resection, which can be combined with other treatments. However, treatment efficacy is poor, and colorectal cancer is prone to relapse and metastasis; thus, identifying an effective anti-cancer drug is an urgent requirement. The present study examined the antagonistic effect of penicillin on cultured colorectal cancer cells and the related mechanism. A MTT assay was used to assess the growth of the colorectal cancer cells treated with penicillin and to determine the optimal drug concentration. The wound healing and Transwell invasion assays were performed to investigate the effect of penicillin on the migration and invasion of the colorectal cancer cells. Live cell mitochondrial energy metabolism analysis was performed to detect changes in mitochondrial energy metabolism of the colorectal cancer cells, while western blot analysis was used to measure the expression of cytochrome $c$ and autophagy-related protein, LC3. RFP-GFP-LC3 lentivirus was used to detect autophagic flux, and autophagosomes were observed using a transmission electron microscope, while flow cytometry was used to analyze the effect of penicillin on cell cycle progression and apoptosis of the colorectal cancer cells. After penicillin treatment, the growth, migration and invasion ability of the colorectal cancer cells were inhibited. The mitochondrial energy metabolism of the cell was impaired, and the basic respiratory capacity, maximum
\end{abstract}

Correspondence to: Professor Shizhong Bu, Diabetes Research Center, School of Medicine, Ningbo University, 818 Fenghua Road, Ningbo, Zhejiang 315211, P.R. China

E-mail: bushizhong@nbu.edu.cn

Professor Wei Cui, Department of Colorectal Surgery, Ningbo Medical Center Lihuili Hospital, 57 XingNing Road, Ningbo, Zhejiang 315211, P.R. China

E-mail: cuiwei1111@live.cn

Key words: penicillin, colorectal cancer, mitochondrial, autophagy, apoptosis respiratory capacity, respiratory potential, and ATP production were all reduced. The protein expression levels of the autophagy-related proteins, LC3-II/LC3-I increased in a dose- and time-dependent manner. In addition, autophagy flux and the number of autophagosomes increased, and mitochondrial structural damage was observed. The cell cycle was arrested at the $G_{1}$ phase, the number of early apoptotic cells increased and the protein expression level of cleaved caspase-3 increased, while penicillin-induced apoptosis was blocked by the autophagy inhibitor 3-MA. In conclusion, penicillin disrupted mitochondrial function and energy metabolism in the colorectal cancer cells, which resulted in the induction of autophagic apoptosis and ultimately the inhibition of cancer cell growth and metastasis.

\section{Introduction}

Colorectal cancer (CRC), including colon and rectal cancer, is the third most common cancer in both males and females, with $\sim 1.36$ million new cases per year and the fourth leading cause of cancer-related deaths worldwide (1). With the development of the economy and changes in the dietary structure of individuals, the morbidity and mortality rates of $\mathrm{CRC}$ have increased in recent years (2-4). The 5-year survival rate of CRC is only 50-60\% (5). At present, the survival time of patients has increased with the development of science and technology, and the improvement of medical standards; however, patients still have poor prognosis and distant metastasis. The quality of life is also affected in patients with CRC (6). Multidisciplinary comprehensive treatment is an important treatment principle for CRC, including surgery, radiation therapy, chemotherapy, immunotherapy and Chinese traditional treatment (7). Surgical treatment to remove the lesion is the preferred treatment for $\mathrm{CRC}$, which also reduces the symptoms, prolongs the life span of the patient and improves the quality of life (8). As the early symptoms of CRC are not obvious, once clinical symptoms appear, the patient is already in late stage cancer, therefore surgery is not suitable and medical treatment is administered instead (9). Traditional anticancer drugs have low selectivity and high toxicity, whereas developing new drugs is time consuming and is associated with high costs. Thus, in recent years, the idea of 'new use of old drugs' provided a new research direction for the treatment of CRC (10). 
Penicillin is an old and widely used antibiotic, with low toxicity and high efficiency (11). It can be used for pharyngitis, scarlet fever, cellulitis caused by hemolytic streptococcus, pneumonia caused by pneumococcus, otitis media, meningitis, tetanus and gas gangrene caused by clostridium (12). The mechanism of action of penicillin is to hinder the formation of the bacterial wall and destroy the structure of the bacterial wall. As human cells have no cell wall, penicillin has the least side effects among various types of antibiotics (13). In addition, penicillin has almost no toxic effects on the human body, and previous studies have used penicillin in human experimental studies, indicating that penicillin is harmless to human cells $(14,15)$. The degradation product of penicillin, as a hapten, which can be combined with protein to produce IgE, which is the basis of immediate allergic reactions (16). There are few studies investigating the use of antibiotics in antitumor treatment alone $(17,18)$, and no reports of the anti-cancer effect of penicillin. In the present study, penicillin was used to treat CRC cells to observe their effects on the growth, migration and invasion.

The mitochondrion is a double-membraned organelle (19). Its main function is to produce ATP via oxidative phosphorylation, to provide energy for eukaryotic cells (20). The second function of mitochondria is associated with apoptosis following changes in mitochondrial membrane permeability (21). Under the stimulation of certain cell death signals, such as reactive oxygen species (ROS. and DNA damage, the outer membrane permeability of mitochondria increases, and a series of changes occur, including cytochrome $c$ release, reduction of the mitochondrial transmembrane potential and a change in the redox state in the cell (22). As a result, the mitochondrial respiratory chain and electron transfer are blocked, and the energy metabolism of the cell is impaired (23). Finally, cytochrome $c$ and other pro-apoptotic proteins (Bax and Bid) are released into the cytoplasm, promoting apoptosis (24).

Autophagy refers to a phenomenon in which cells use lysosomes to degrade misfolded proteins or damaged organelles to maintain a normal intracellular environment, which is common in eukaryotic cells (25). Studies have found that autophagy has a two-way role in the survival and death of tumor cells $(26,27)$. Moderate autophagy can clear damaged organelles, so that cells can respond correctly to external stimuli and damage, and survive. However, excessive autophagy can promote cell apoptosis and cause cell damage (28). During autophagy, microtubule-associated protein 1 light chain 3 (LC3) enzymatically decomposes a small piece of polypeptide and becomes LC3-I, after which LC3-I binds with phosphatidylethanolamine to become LC3-II. Therefore, the ratio of LC3-II/LC3-I is often used in experimental studies to assess the level of autophagy (29). In another study, the mRFP-GFP-LC3 dual-fluorescence autophagy system was used to track changes in LC3 and the autophagic flux. The level of autophagy activity and autophagic flux was evaluated by observing the bright spots of green fluorescent protein (FP) and monomeric red FP under fluorescence and confocal microscopy (30). Observation of autophagosomes by transmission electron microscopy is the gold standard for determining changes in autophagy. Under electron microscopy, autophagosomes appear as double-layered or multi-layered vacuoles containing cytoplasmic components, including mitochondria, endoplasmic reticulum, and ribosomes (31).
In the present study the effect of penicillin on the growth and metastasis of CRC cells was investigated first, then the underlying mechanism. The results provide a new experimental basis and research direction for the clinical treatment of CRC.

\section{Materials and methods}

Cell culture and treatment. The human CRC cell lines, HCT116, HT29 and SW620 were purchased from the Cell Bank of Shanghai Chinese Academy of Sciences. Long-acting penicillin (powder was purchased from North China Pharmaceutical Group Corp and dissolved in PBS. The cells were cultured in RPMI-1640 (Gibco; Thermo Fisher Scientific, Inc.), supplemented with 10\% FBS (Gibco; Thermo Fisher Scientific, Inc. and $1 \%$ (Penicillin/Streptomycin) at $37^{\circ} \mathrm{C}$ in a humidified incubator with $5 \% \mathrm{CO}_{2}$.

Western blot analysis. The HCT-116 cell line was washed twice with PBS and lysed in RIPA buffer (Beijing Solarbio Science and Technology Co., Ltd.) containing $2 \mathrm{mM}$ phenylmethylsulfonyl fluoride (PMSF). Protein concentration was determined using the bicinchoninic acid method (CoWin Biosciences). The proteins were separated using 12\% SDS-PAGE and transferred to $0.45 \mu \mathrm{m}$ PVDF membranes, blocked with $10 \%$ skimmed milk at room temperature for $2 \mathrm{~h}$. The membrane was then incubated with the following primary antibodies overnight at $4^{\circ} \mathrm{C}$ : $\beta$-actin $(1: 1,000$; cat. no. 4ab020185; 4A Biotech Co., Ltd.), LC3 (1:1,000; cat. no. NB100-2220; Novus Biologicals), cytochrome $c(1: 1,000$; cat. no. NB100-56503; Novus Biologicals), cleaved caspase-3 (1:1,000; cat. no. 9661; Cell Signaling Technology, Inc.), caspase-3 (1:1,000; cat. no. 14220; Cell Signaling Technology, Inc.), COX4 (1:1,000; cat. no. 4844; Cell Signaling Technology, Inc.). Then, the membrane was incubated with HRP-labeled secondary antibodies [(goat anti-rat, cat. no. A0192; goat anti-rabbit, (cat. no. A0208) (both 1:10,000) (both from Beyotime Institute of Biotechnology)] at room temperature for $1 \mathrm{~h}$. The proteins bands were detected with a gel imaging and analysis system (Tanon Scuence and Technology Co., Ltd.). Densitometry was performed using ImageJ software (National Institutes of Health). The HCT-116 cells were seeded into 6-well plates, at a density of $5.0 \times 10^{5}$, cells/well in $2 \mathrm{ml}$ medium, then divided into four groups: Control, 10 mM 3-methyladenine (3'MA; MedChemExpress), $500 \mathrm{U} / \mathrm{ml}$ penicillin and penicillin+3-MA groups. After the cells were incubated for $24 \mathrm{~h}$, the protein was extracted for western blot analysis.

Mitochondrial isolation. The HCT116 cell line $\left(1 \times 10^{7}\right)$ was collected and washed with PBS, and cytochrome $c$ release was determined using a mitochondrial isolation kit (Beyotime Institute of Biotechnology). First, Mitochondria Isolation Solution containing PMSF (Beijing Soleibao Technology Co., Ltd., China) was added to the cells and they were incubated in an ice bath for $15 \mathrm{~min}$. A glass homogenizer was used to grind the cells followed by centrifugation at $1,000 \mathrm{x}$ g for $10 \mathrm{~min}$ at $4^{\circ} \mathrm{C}$. The liquid supernatant was moved to a fresh tube and centrifuged again at $11,000 \mathrm{x}$ g for $10 \mathrm{~min}$ at $4^{\circ} \mathrm{C}$. The sediment was mixed with Mitochondrial Lysate Solution to obtain the mitochondrial proteins. The supernatant was centrifuged 
at $12,000 \mathrm{x} \mathrm{g}$ for $20 \mathrm{~min}$ at $4^{\circ} \mathrm{C}$ to obtain cytosolic proteins, then analyzed using western blot analysis.

Cell viability assay. Viability of the HCT-116, HT-29 and SW620 cell lines was determined using a MTT assay at the indicated times. The HCT-116, HT29 and SW620 cell lines $\left(2 \times 10^{3}\right.$ cells/well) were seeded in 96-well plates (Corning Inc.) and cultured for $24 \mathrm{~h}$ in RPMI-1640 supplemented with $10 \%$ FBS. The cells were then treated with penicillin $(0,50,100,200,500$ and $1,000 \mathrm{U} / \mathrm{ml})$ for $1-4$ days, then $10 \mu \mathrm{l}$ MTT (Sigma-Aldrich, Merck KGaA) solution $(5 \mathrm{mg} / \mathrm{ml}$ in PBS) was added to each well. The plates were incubated for another $3-4 \mathrm{~h}$ at $37^{\circ} \mathrm{C}$. Intracellular formazan crystals were dissolved by adding $100 \mu \mathrm{l}$ dimethyl sulfoxide (Sigma-Aldrich; Merck KGaA) to each well. Cell proliferation was determined by measuring the absorbance at $490 \mathrm{~nm}$ with a spectrophotometer (Multiskan MK3; Thermo Fisher Scientific, Inc.). The experiments were performed 3 times.

Wound healing assay. For the wound healing assay, the HCT-116, HT-29 and SW620 cell lines $\left(3-5 \times 10^{5}\right.$ cells/well) were seeded in 6-well plates and cultured until $100 \%$ confluence. The monolayer was carefully scratched with a sterile $200 \mu$ l pipette tip. Floating cells were removed by a gentle wash with cold PBS, then cells were cultured with RPMI-1640 containing $2 \% \mathrm{FBS}$ and incubated with or without long-acting penicillin $(500 \mathrm{U} / \mathrm{ml})$ for $72 \mathrm{~h}$. Representative images were captured under an inversion fluorescence microscope and the gap closures were quantitated using the ImageJ software (v1.8.0.112; National Institutes of Health). All the experiments were performed at least 3 times.

Transwell invasion assay. Transwell invasion assays were performed using Transwell chambers with $8-\mu \mathrm{m}$ pore size filter membranes (EMD Millipore). The polycarbonate filter was coated with Matrigel (30 $\mu \mathrm{g} / \mathrm{well}$; BD Matrigel Matrix) at $37^{\circ} \mathrm{C}$ for $1 \mathrm{~h}$. Then, the chambers were inserted into 24-well culture plates. The HCT-116, HT-29 and SW620 cell lines were starved overnight in assay media (RPMI-1640 without FBS), then single-cell suspensions were seeded into the upper chamber $\left(5 \times 10^{4}\right.$ cells/well in RPMI-1640 without FBS). The lower chamber was filled with $600 \mu 1$ RPMI-1640 containing $10 \% \mathrm{FBS}$. Following incubation at $37^{\circ} \mathrm{C}$ for $24 \mathrm{~h}$, the non-invaded cells on the upper side of the filter were removed with a cotton swab. The invaded cells were fixed in methanol for $30 \mathrm{~min}$ at room temperature, stained with $0.1 \%$ crystal violet at room temperature for $15 \mathrm{~min}$, and observed under a fluorescent microscope (Olympus corporation at x100 magnification. All the experiments were performed at least 3 times.

Immunofluorescence. The HCT-116 cells were seeded at $1 \times 10^{4}$ cells $/ \mathrm{ml}$ in an 8 -well plate and transfected with the GFP-RFP-LC3 lentivirus after cell adherence. Tandem fluorescent-tagged LC3 (GFP-RFP-LC3) lentiviral vector was purchased from Shanghai GeneChem Co., Ltd. The cells were treated with long-acting penicillin $(500 \mathrm{U} / \mathrm{ml})$ for 1 day following transfection for $72 \mathrm{~h}$, then observed under a confocal microscope (Olympus Corp.). After the cells were transfected with LC3-GFP-RFP lentivirus, LC3 had both green and red colors in the cytoplasm, but only showed green puncta when in the autophagolysosomes. All the experiments were performed at least 3 times.

Flow cytometry. Apoptosis of the HCT-116 cell line was determined using the Annexin V-PE Apoptosis Detection kit (BD Biosciences). Briefly, the cells were seeded into 6 -well plates, then treated with long-acting penicillin $(0,50,100,200$ and $500 \mathrm{U} / \mathrm{ml})$ at $37^{\circ} \mathrm{C}$ for $24 \mathrm{~h}$. Following which, the cells were washed twice with cold PBS, then resuspended in $1 \mathrm{X}$ binding buffer. A total of $100 \mu \mathrm{l}$ cell suspension was transferred to a $1.5 \mathrm{ml}$ culture tube, to which $1 \mu \mathrm{l}$ Annexin $\mathrm{V}-\mathrm{PE}$ and $1 \mu 1$ 7-AAD were added. The mixture was incubated for $15 \mathrm{~min}$ at room temperature in the dark. The results were immediately analyzed using a FACS flow cytometer (FACSARIA II; BD Biosciences) and the FlowJo software (v10.0.7r2; FlowJo LLC). All experiments were performed at least 3 times.

The cell cycle staining solution (MultiSciences Biotech Co., Ltd.) was used to analyze the cell cycle of the cells. The HCT-116 cell line was seeded $\left(5 \times 10^{5}\right.$ cells/well) into 6-well plates, then treated with long-acting penicillin $(0,50,100,200$ and $500 \mathrm{U} / \mathrm{ml}$ ) at $37^{\circ} \mathrm{C}$ for $24 \mathrm{~h}$. The treated and untreated cells were washed twice in cold PBS. After centrifugation at 2,000 x g for $3 \mathrm{~min}$ at $4{ }^{\circ} \mathrm{C}$, the washed pellets were resuspended in $300 \mu \mathrm{l}$ DNA staining solution, containing $3 \mu \mathrm{l}$ permeabilization solution and incubated at room temperature for $30 \mathrm{~min}$ in the dark. DNA content was analyzed using a flow cytometer (FACSARIA II; BD Biosciences). The results were analyzed using the cell cycle analysis software ModFit LT v4.1 (Verity Software House, Inc.,). All the experiments were performed at least 3 times.

Electron microscopy. The HCT-116 cell line was fixed in $4 \%$ paraformaldehyde in $0.1 \mathrm{M}$ phosphate buffer for $4 \mathrm{~h}$ at $4^{\circ} \mathrm{C}$. The cells were washed with $0.1 \mathrm{M}$ phosphate buffer and post-fixed in $1 \%$ osmium tetroxide for $2 \mathrm{~h}$ at $4^{\circ} \mathrm{C}$. Then, the cells were dehydrated with ethanol and embedded in Epon-812 resin, and, finally, polymerized for 2 days at $65^{\circ} \mathrm{C}$. Ultrathin sections (70 to $90 \mathrm{~nm}$ ) were stained with uranyl acetate and lead citrate at room temperature for $30 \mathrm{~min}$. The ultrathin sections were observed under a Hitachi-7000 electron microscope (Hitachi Ltd.).

Energy metabolism analysis of living cell mitochondria. The HCT-116 cell line was transferred at a density of $1 \times 10^{4}$ cells/well in unbuffered DMEM (Gibco; Thermo Fisher Scientific, Inc.) at $\mathrm{pH} 7.4$ to an XF24 Seahorse assay plate to measure the mitochondrial oxygen consumption rate (OCR) with an XF analyzer (XF24; Seahorse Bioscience, Inc.) at different time points $(0,20,40,60$ and $80 \mathrm{~min})$. The cells were incubated at $37^{\circ} \mathrm{C}$ without $\mathrm{CO}_{2}$ for $1 \mathrm{~h}$ for equilibration before initiating the assay. To measure bioenergetics, the basic OCR was measured first. The cells were treated with oligomycin (1 $\mu \mathrm{mol} / \mathrm{l})$ to inhibit ATP synthase, then carbonyl cyanide was added to trifluoromethoxyphenyl hydr $(1 \mu \mathrm{mol} / \mathrm{l})$ to produce maximum uncoupled respiration. Non-mitochondrial respiration was determined by adding rotenone $(0.5 \mu \mathrm{M})$ and antimycin $\mathrm{A}(0.5 \mu \mathrm{M})$. Under these well-defined conditions, the effects of penicillin on the mitochondrial basal respiration, 
A
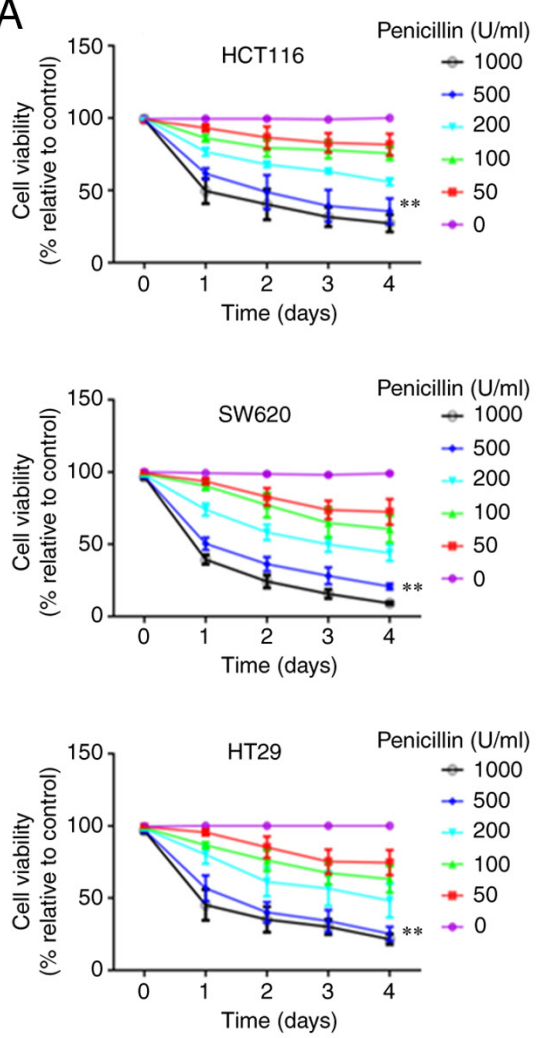

B
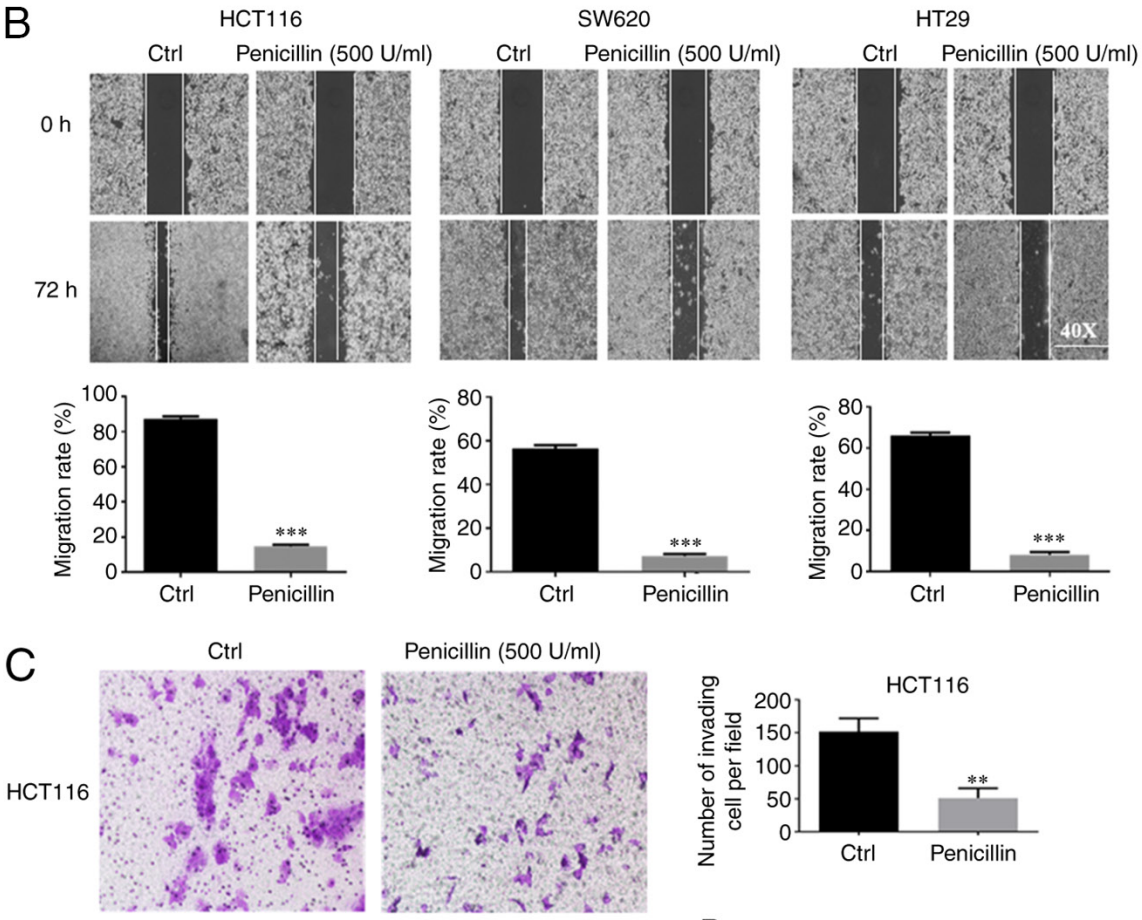

Penicillin $(500 \mathrm{U} / \mathrm{ml})$
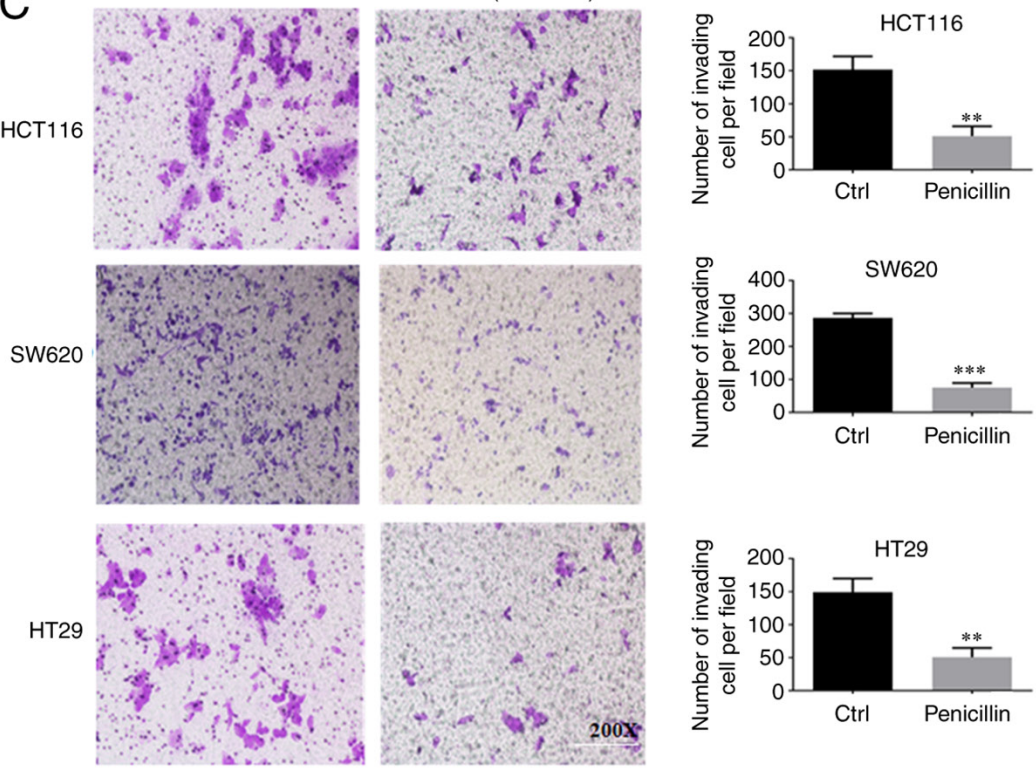

Figure 1. Penicillin has an inhibitory effect on the growth, migration and invasion of the CRC cell lines. (A) MTT, (B) wound healing and (C) Transwell invasion assays showed that penicillin inhibited the growth, migration and invasion of the $3 \mathrm{CRC}$ cell lines. ${ }^{* *} \mathrm{P}<0.01$, **** $\mathrm{P}<0.001 \mathrm{vs}$. control. $\mathrm{Ctrl}$, control.

ATP-linked respiration, maximum respiration capacity and reserve respiration capacity of the CRC cells was analyzed.

Statistical analysis. SPSS v19.0 (IBM Corp.) was used for data analysis and GraphPad Primer v8 (GraphPad Software, Inc.) was used for graph generation. Data conforming to the normal distribution are presented as the mean \pm SD. An unpaired t-test was used to compare two groups and one-way ANOVA followed by Bonferroni's post hoc test was used to compare $>2$ groups. $\mathrm{P}<0.05$ was considered to indicate a statistically significant difference.

\section{Results}

Penicillin has an inhibitory effect on the growth, migration and invasion of the CRC cell lines. First, 0-1,000 U/ml long-acting penicillin was used to treat the HCT-116, HT29 and SW620 cell lines to determine its effect on cell growth. As shown in Fig. 1A, as the concentration of long-acting penicillin increased, the activity of the CRC cells gradually weakened. In addition, cell viability decreased after the first day, and
$500 \mathrm{U} / \mathrm{ml}$ was the most effective inhibition concentration. At $1,000 \mathrm{U} / \mathrm{ml}$, the inhibitory effect on cells began to stabilize. The results of the three CRC cell lines showed the same trend.

Next, the most effective inhibitory concentration of long-acting penicillin $(500 \mathrm{U} / \mathrm{ml})$ was used to treat the CRC cell lines to determine its effect on the migration and invasion abilities of the CRC cell lines. As shown in Fig. 1B, at $72 \mathrm{~h}$, the control group of the three different CRC cell lines had migrated substantially toward the middle of the scratch, while the penicillin-treated cells migrated significantly less compared with that in the control group. As shown in Fig. 1C, for all three cell lines, the control group had more invading cells compared with that in the penicillin group. Thus, penicillin could inhibit the migration and invasion abilities of the CRC cell lines.

Penicillin disrupts mitochondrial function of the HCT-116 cell line. To investigate whether penicillin caused dysregulation of mitochondrial energy metabolism in the HCT-116 cell line, a mitochondrial energy metabolism experiment was performed and the results are shown in Fig. 2A. After treatment of the HCT-116 cells with long-acting penicillin $(250$ and $500 \mathrm{U} / \mathrm{ml})$ 
A
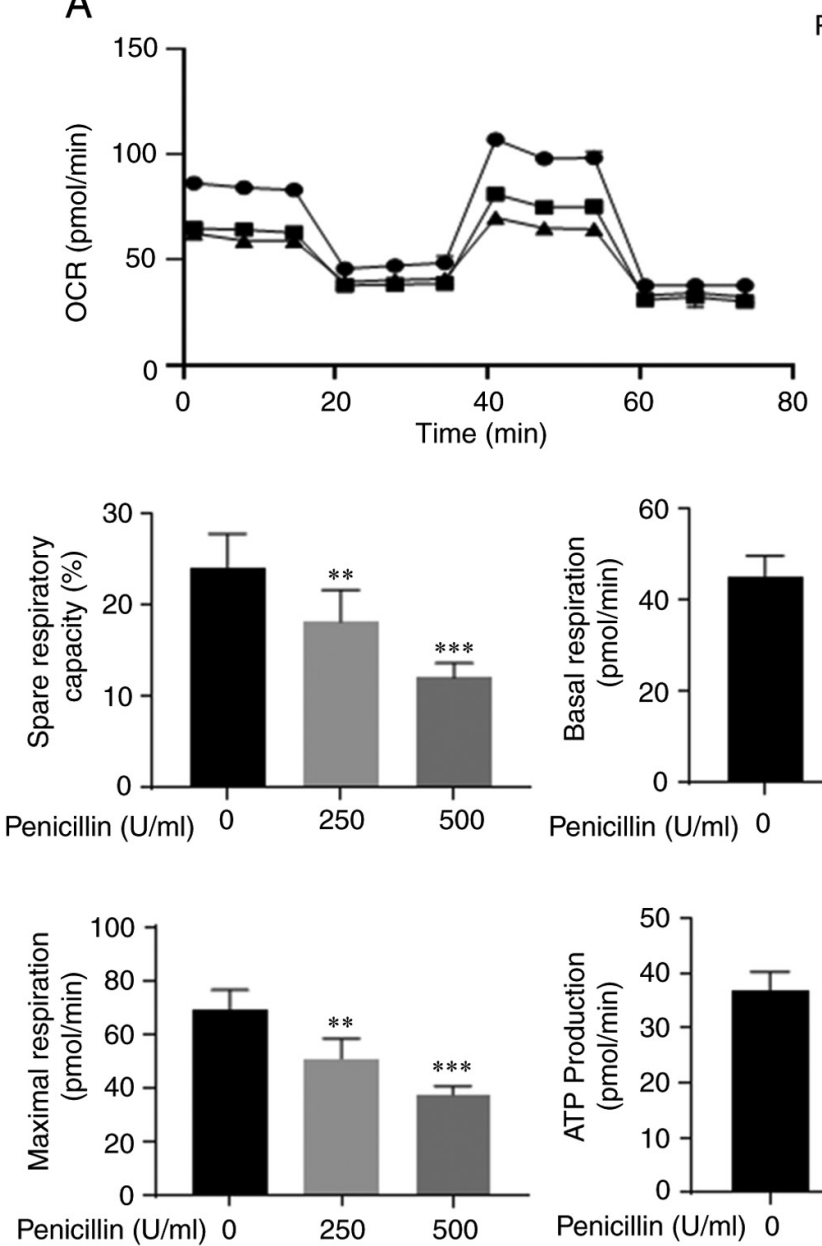

Penicillin $(\mathrm{U} / \mathrm{ml})$

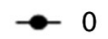

$-250$

$\mp 500$
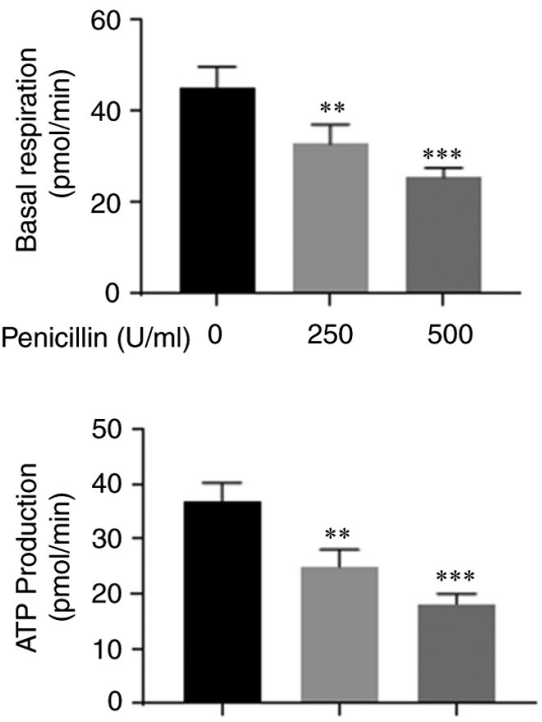

Penicillin $(\mathrm{U} / \mathrm{ml}) \quad 0$

250

500
B
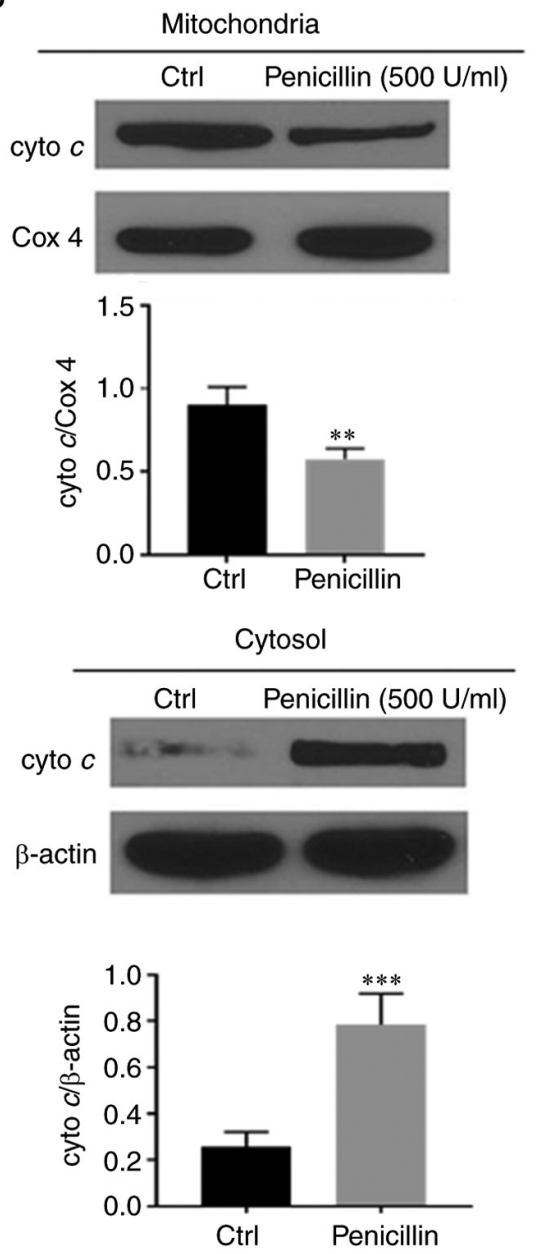

Figure 2. Penicillin disrupts mitochondrial function of the HCT116 cell line. (A) The mitochondrial energy metabolism experiment showed changes in respiration rates and ATP production in the HCT116 cell line treated with penicillin. (B) Proteins from mitochondria and cytoplasm were extracted and detected using western blot analysis, and normalized to COX4 in the mitochondria and $\beta$-actin in the cytosol in the HCT116 cell line. ${ }^{* *} \mathrm{P}<0.01$, ${ }^{* * *} \mathrm{P}<0.001$ vs. control. Ctrl, control; Cyto $c$, cytochrome $c$.

for $24 \mathrm{~h}$, the entire OCR curve of the HCT-116 cell line mitochondrial aerobic respiration shifted downward. A significant change was observed even at a $250 \mathrm{U} / \mathrm{ml}$. In addition, inhibition was observed for the main parameters of mitochondrial aerobic respiration, including basal respiration capacity, ATP production, maximum respiration capacity and respiration potential. To further determine whether dysfunction of the mitochondria in the HCT-116 cell line occurred, western blot analysis was used to measure cytochrome $c$ protein expression and the results are shown in Fig. 2B. After the HCT116 cell line was treated with $500 \mathrm{U} / \mathrm{ml}$ penicillin, the cytochrome $c$ protein expression level in the mitochondria and the cytoplasm was measured. The results showed that the protein expression level of cytochrome $c$ in the mitochondria and cytoplasm decreased and increased, respectively indicating that cytochrome $c$ moved from the mitochondria into the cytoplasm. Thus, penicillin could cause energy metabolism disorders in the mitochondria of CRC cell lines.

Penicillin induces autophagy in the HCT-116 cell line. To investigate the effect of penicillin on autophagy in the HCT-116 cell line, western blot analysis of autophagy-related proteins, transmission electron microscope and LC3 autophagy lentivirus were used to examine the level of autophagy. First, different concentrations of long-acting penicillin $(0,50,100,200$, and $500 \mathrm{U} / \mathrm{ml}$ ) were used to treat the HCT-116 cell line for $24 \mathrm{~h}$, then long-acting penicillin at $500 \mathrm{U} / \mathrm{ml}$ was also added to the cells for different periods of time ( $(0,1,2$ and 3 days) to observe the protein expression level of autophagy-related protein, LC3. As shown in Fig. 3A, penicillin increased the conversion of cytoplasmic LC3-I to membrane-type LC3-II and the expression level of LC3-II/LC3-I increased with the increase in penicillin concentration, showing dose dependence.

Transmission electron microscopy was also used to further observe changes in autophagosomes after penicillin treatment of the HCT-116 cell line. As shown in Fig. 3B, after the HCT-116 cell line was treated with $500 \mathrm{U} / \mathrm{ml}$ long-acting penicillin for $24 \mathrm{~h}$, autophagosomes with double membrane structure (blue arrows) were observed under the electron microscope, mainly mitochondrial swelling and irregular mitochondrial crest. The control group showed normal mitochondria (red arrows), and no autophagosomes. Therefore, penicillin could induce autophagy in the HCT-116 cell line and could damage the mitochondrial structure of CRC cells.

As shown in Fig. 3C, after treating the HCT-116 cell line with $500 \mathrm{U} / \mathrm{ml}$ long-acting penicillin for $24 \mathrm{~h}$, GFP-LC3 green fluorescent spots, RFP-LC3 red fluorescent spots, and 
A
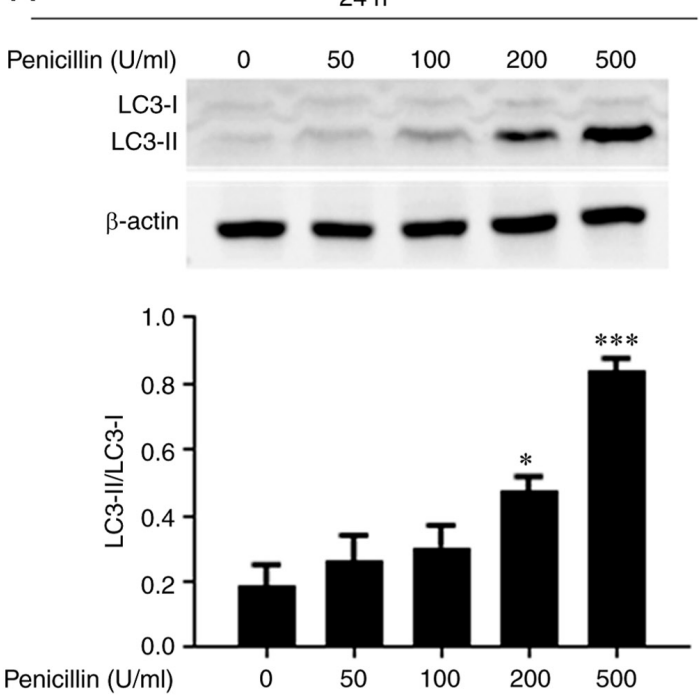

B

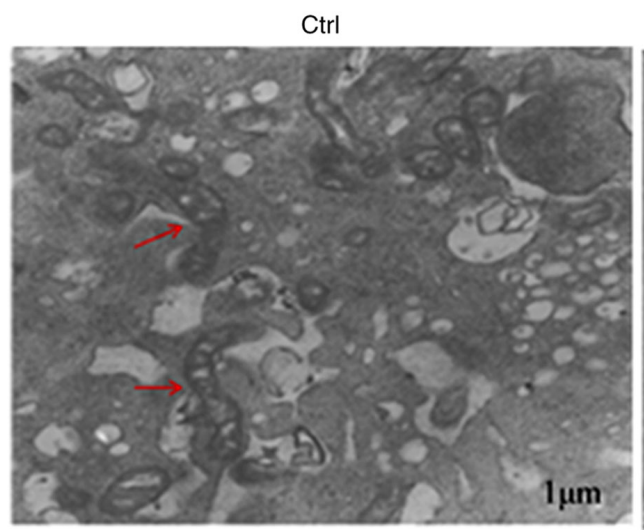

C
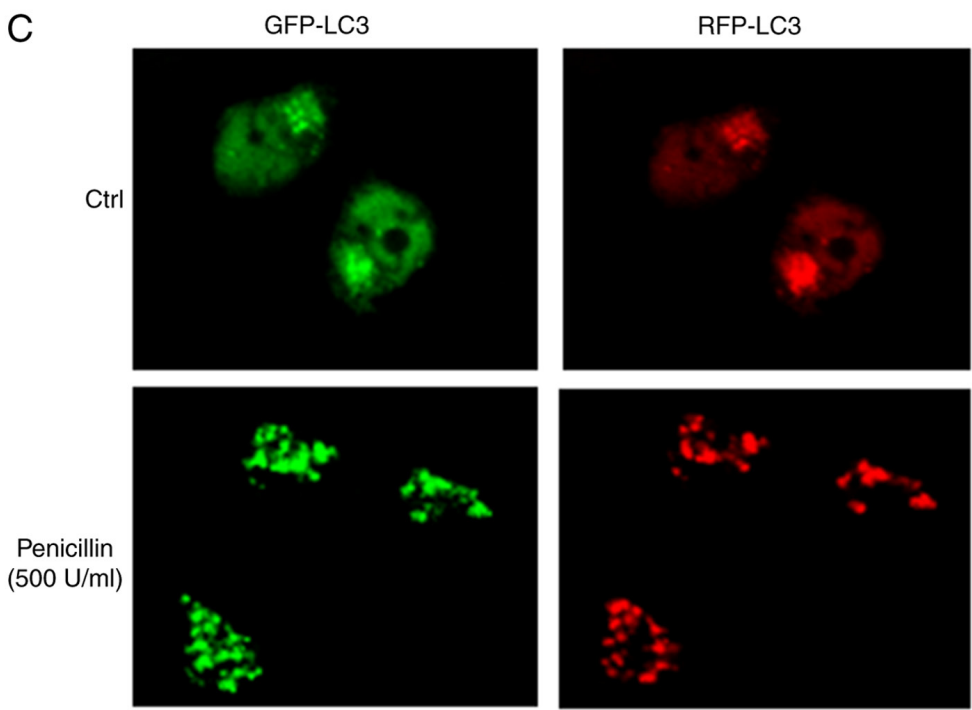

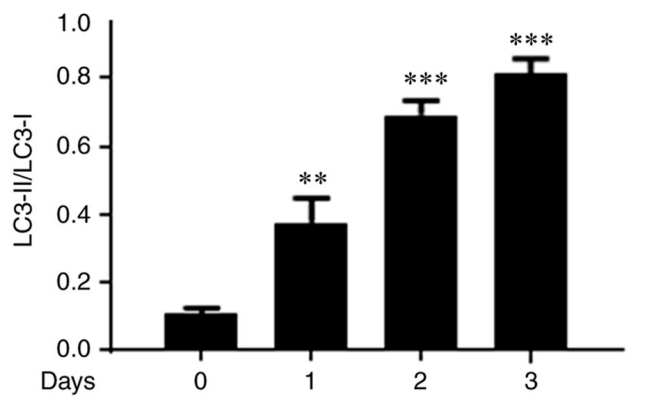

Penicillin $500 \mathrm{U} / \mathrm{ml}$

Penicillin $500 \mathrm{U} / \mathrm{ml}$

\begin{tabular}{|c|c|c|c|c|c|}
\hline & 0 & 1 & 2 & 3 & (days) \\
\hline LC3-I & 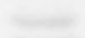 & 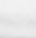 & 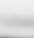 & $=$ & \\
\hline LC3-II & $1=$ & 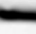 & & & \\
\hline
\end{tabular}
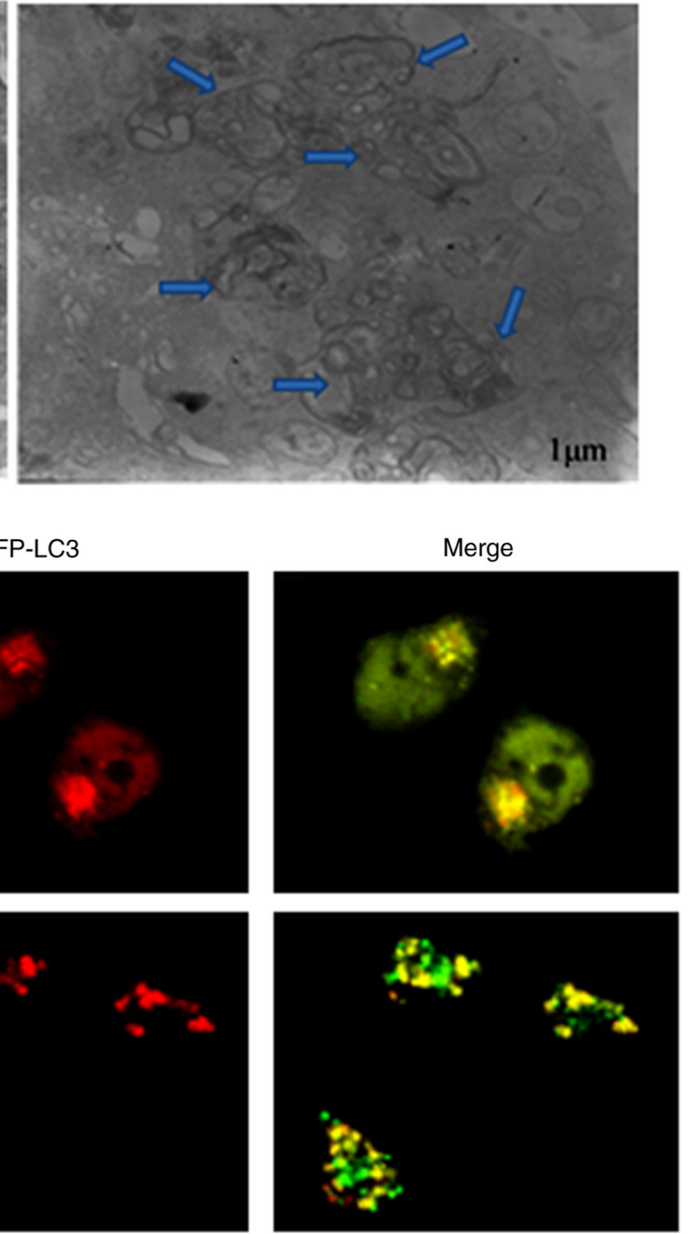

Figure 3. Penicillin induces autophagic apoptosis in the HCT116 cell line. (A) Western blot analysis showed that the expression level of the autophagy-related proteins LC3II/LC3-I was upregulated. ${ }^{*} \mathrm{P}<0.05,{ }^{* *} \mathrm{P}<0.01,{ }^{* * * *} \mathrm{P}<0.001$ vs. control. (B) The HCT116 cell line was treated with long-acting penicillin $500 \mathrm{U} / \mathrm{ml}$ for $24 \mathrm{~h}$, and the changes in autophagosomes were observed under a confocal microscope after LC3 lentivirus infection. Magnification, $\mathrm{x} 600$. (C) Transmission electron microscopy showed increased autophagosomes and damage to the mitochondria. The red arrows indicate normal mitochondria, the blue arrows indicate autophagosomes. Magnification x12,000. Ctrl, control.

RFP-LC3 and GFP-LC3 double-positive fluorescent spots all increased, further demonstrating that following penicillin treatment of the HCT-116 cells, intracellular autophagosomes and autophagy increased.
Effects of penicillin on the cell cycle and apoptosis in the HCT116 cell line. Next, flow cytometry was used to examine the effect of penicillin on the cell cycle and cell apoptosis in the HCT-116 cell line. Different concentrations of long-acting 

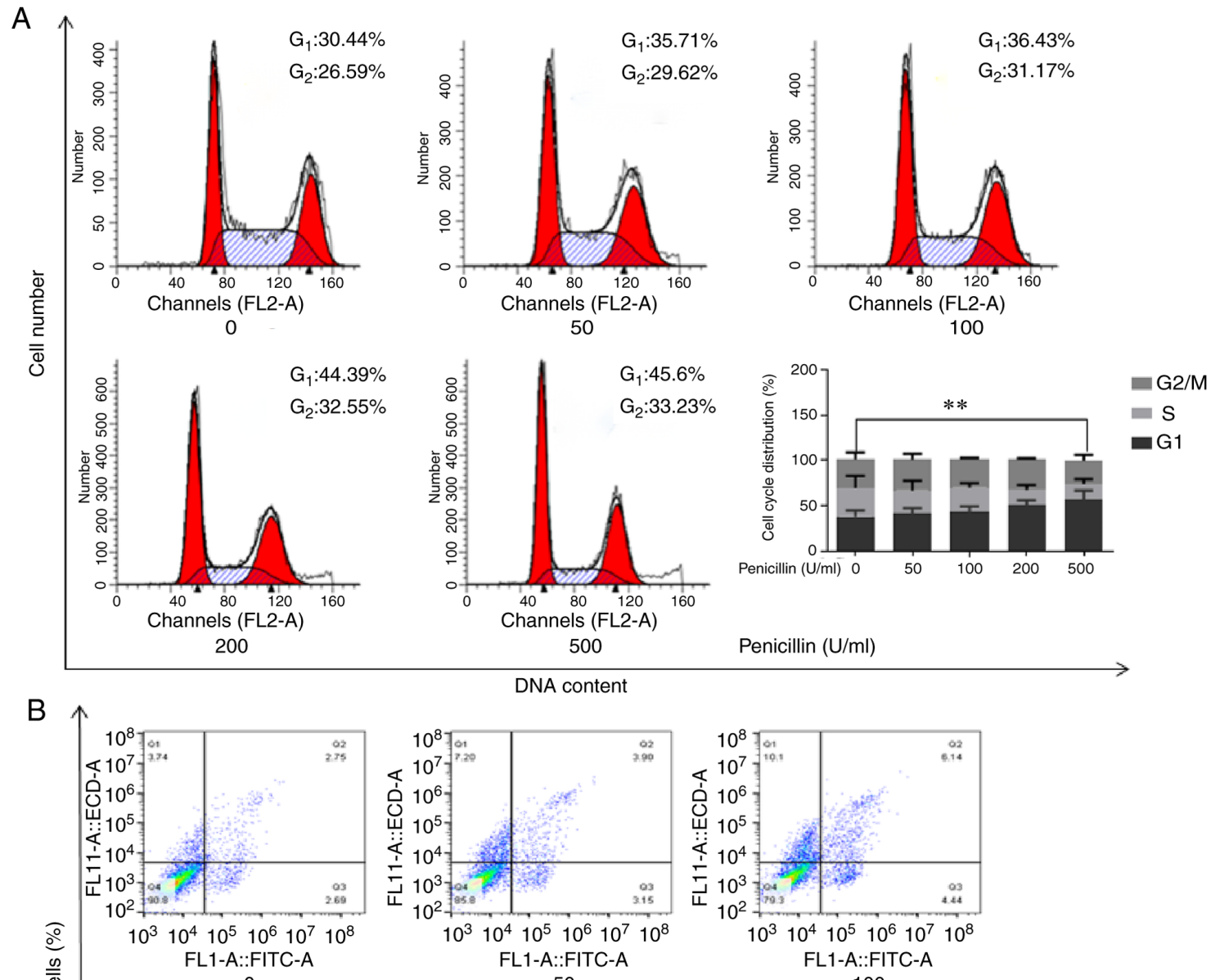

50

100
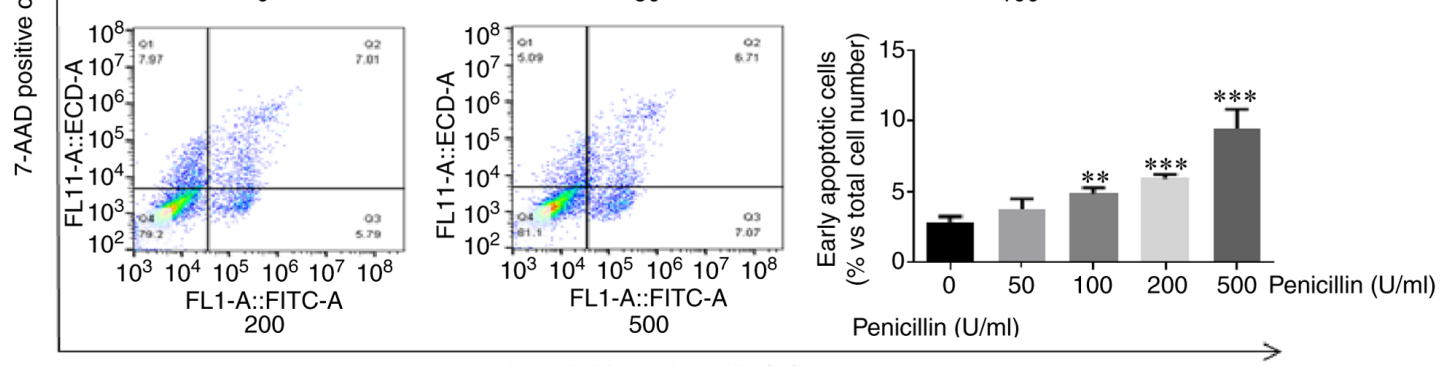

Annexin $\mathrm{V}$ positive cells (\%)

C
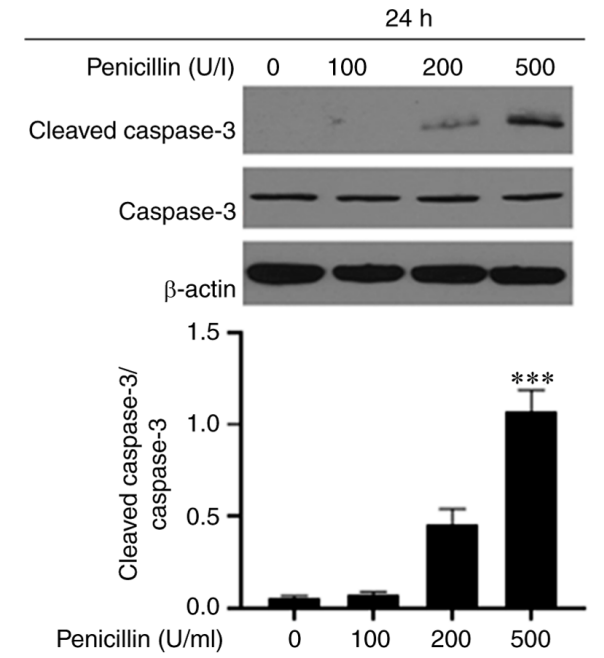
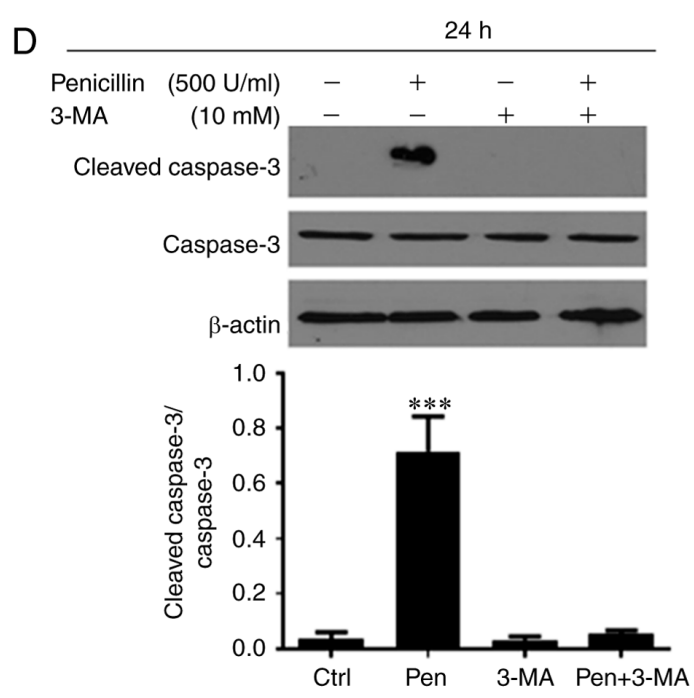

Figure 4. Penicillin blocks the CRC cell cycle in the G1 phase and increases the number of early apoptotic cells in the HCT116 cell line. The HCT116 cell line was treated with long-acting penicillin $(0,50,100,200$, and $500 \mathrm{U} / \mathrm{ml}$. for $24 \mathrm{~h}$, then (A) cell cycle and (B) apoptosis was analyzed. (C) Different concentrations of penicillin $(0,100,200,500 \mathrm{U} / \mathrm{ml})$ were added to the HCT116 cell line for $24 \mathrm{~h}$ and the protein expression level of cleaved caspase- 3 was increased and was dose-dependent. (D) After the autophagy inhibitor, 3-MA inhibited autophagy, the protein expression level of caspase-3 was decreased. ${ }^{* *} \mathrm{P}<0.01,{ }^{* * *} \mathrm{P}<0.001$ vs. control. Ctrl, control; pen, penicillin. 
penicillin $(0,50,100,200$, and $500 \mathrm{U} / \mathrm{ml})$ were used to treat the HCT-116 cell line for $24 \mathrm{~h}$ and the results are shown in Fig. 4. Penicillin significantly increased the number of HCT-116 cells in the $\mathrm{G}_{1}$ phase and decreased the number of cells in the $\mathrm{S}$ phase, indicating that penicillin could block cell cycle progression in the HCT-116 cell line at the $\mathrm{G}_{1}$ phase. A concentration dependence was also observed. In addition, after treatment with long-acting penicillin, the percentage of early apoptotic cells increased significantly. Furthermore, different concentrations of penicillin $(0,100,200,500 \mathrm{U} / \mathrm{ml})$ were added to the HCT-116 cell line for $24 \mathrm{~h}$, then western blot analysis was used to detect the expression of apoptosis-related protein, caspase-3. The results showed that penicillin could promote the apoptosis of the HCT-116 cell line. After the autophagy inhibitor, 3-MA inhibited autophagy, the protein expression level of caspase-3 was downregulated.

\section{Discussion}

As a common malignant tumor in the world, CRC is one of the leading causes of cancer-associated death. In recent years, the number of new patients with CRC has exceeded 1 million, resulting in 700,000 deaths worldwide each year (32). Therefore, identifying a safe and effective drug is important in the current research on CRC. Previously, it has been reported that antibiotics could enhance the therapeutic effect of chemotherapy drugs on CRC (33); however, to the best of our knowledge, there has been no report on whether antibiotics alone can treat tumors. Penicillin is an antibacterial drug commonly used in clinical practice; it has few toxic side effects and is cheaper compared with other antibiotics (streptomycin, cephalosporins and vancomycin) (34). In view of its clinical safety, we hypothesized that it could be used in antitumor therapy.

In the present study, long-acting penicillin was used to treat the CRC cell lines and it was found that penicillin inhibited the growth of the CRC cell lines, and $500 \mathrm{U} / \mathrm{ml}$ was the optimal inhibitory concentration. In addition, the wound healing and Transwell invasion assays showed that penicillin significantly inhibited the migration and invasion of the CRC cell lines. These findings suggested that penicillin had antitumor properties, and could inhibit the growth, migration and invasion of the CRC cell lines. During normal cell growth, abnormal apoptosis and cell cycle progression can cause malignant cells to proliferate. Inhibiting tumor cell proliferation can be achieved by regulating abnormal cell apoptosis and abnormal cell cycle (35). In the present study, it was found that penicillin blocked the cell cycle of the HCT116 cell line at the $\mathrm{G}_{1}$ phase and increased the number of early apoptotic cells, suggesting that penicillin could increase the apoptosis by blocking the cell cycle.

Studies have shown that mitochondria not only produce and provide energy, but also participate in a variety of physiological and pathological reactions $(21,36,37)$. Mitochondrial dysfunction can lead to various pathological changes, such as the inflammatory response, oxidative stress response and apoptosis. Changes caused by mitochondrial structure and function injury, such as abnormal function of cellular respiratory chain enzymes, membrane potential decline and permeability change, calcium ion overload and pro-apoptotic protein overexpression, ultimately lead to apoptosis and are an important way to inhibit cell growth (38). The release of cytochrome $c$ is associated with the increase in mitochondrial outer membrane permeability and membrane potential (39). Existing studies show that CRC cell growth inhibition and mitochondrial function is associated (40-42). To identify the mechanism by which penicillin inhibited CRC cell growth migration and invasion, mitochondrial energy metabolism was analyzed to examine the cell mitochondrial energy metabolism, and it was found that penicillin caused mitochondria energy metabolic disorders, where basic respiration capacity, maximal respiration capacity, respiration potential, and ATP generation were significantly inhibited. Mitochondrial energy metabolism disorder leads to increased mitochondrial membrane permeability, which releases cytochrome $c$ into the cytoplasm, further promoting the release of apoptotic factors and finally leading to cell apoptosis (43). In the present study, the protein expression level of cytochrome $c$ was significantly upregulated by penicillin treatment in a dose-dependent manner. This suggested that penicillin caused mitochondrial function damage in the HCT116 cell line, led to energy metabolism disorder and promoted the release of cytochrome $c$.

There are numerous ways to induce tumor cell death, including several non-apoptotic forms of death in addition to apoptosis, in which autophagic cell death is an important one (44). Autophagy is a basic physiological process widely present in eukaryotic cells. It removes harmful protein aggregates, damaged organelles and some pathogens through lysosomal degradation, to maintain the homeostasis of the cells $(45,46)$. Appropriate autophagy is crucial to cell homeostasis, but if autophagy is dysregulated, it causes a several diseases, including neurodegeneration and tumors, and excessive autophagy can lead to cell death (47). Therefore, autophagy plays an important role in antitumor drug therapy. In the present study, penicillin induced autophagy in the HCT116 cell line, which in turn caused apoptosis. LC3 is known to be in two forms, LC3-I and LC3-II. When autophagy begins, inactive LC3-I binds with phosphatidylethanolamine and is transformed into the active LC3-II, and activated LC3-II aggregates on the autophagic membrane; therefore, the ratio of LC3-II/LC3-I reflects the degree of autophagy to a certain extent $(48,49)$. In the present study, the ratio of LC3-II/LC3-I was significantly upregulated by penicillin in a time- and dose-dependent manner. The number of autophagosomes increased following penicillin treatment as observed using confocal microscopy. Furthermore, mitochondrial structure damage was observed with transmission electron microscopy.

Some studies have shown that the use of antibiotics increases the risk of CRC or colorectal adenoma, particularly in the proximal colon $(50,51)$, and other studies have shown that long-term antibiotics, such as tetracycline, can reduce the risk of rectal cancer $(52,53)$. A previous study also showed that when the ampicillin/amoxicillin treatment strategy is switched from anti-anaerobic to anti-aerobic, the incidence of CRC is reversed (54). The size and pattern of the effect of oral antibiotics on the risk of CRC differs depending on the anatomical location of the cancer. The proximal colon is the first location to be exposed to antibiotics and different colorectal anatomical locations determine the distribution of different advocacy flora (55). Oral anti-anaerobic drugs can destroy the microbiota organization and structure in the colon and significantly impact the risk of CRC (56). As the 
intestinal flora is mainly composed of anaerobic bacteria, it is of note that the CRC tissue is rich in a multi-microbial invasive biofilm, particularly the right tumor (57). The greater impact of antibiotics on the proximal colon may reflect the destruction of biofilm formation related to carcinogenesis (51). Antibiotics can reduce the risk of $\mathrm{CRC}$; however, the intestinal flora is also affected. In the current study, it was found that penicillin had an antitumor effect, which is a new finding; however, further research should be performed in a clinical setting.

In conclusion, the role of penicillin in antimicrobial therapy has been widely known; however, reports of penicillin use in antineoplastic therapy are rare. In the present study, using cultured CRC cell lines it was demonstrated that penicillin could inhibit the growth and promote CRC cell apoptosis. The results provide the basis for evaluating the antitumor effects of penicillin. To further understand the antitumor properties of penicillin, the inhibitory effects of penicillin on CRC cells should be investigated in animal experiments, which is the aim of our future experiments, to establish a cell derived xenograft tumor model to further verify the inhibitory effect of penicillin on CRC cell lines. Such experiments would further reveal the effects of penicillin on the growth and metastasis of CRC cells, and provide a basis for the clinical treatment of CRC.

\section{Acknowledgements}

Not applicable.

\section{Funding}

This study was supported by Ningbo Science and Technology Innovation Team Program (grant no. 2014B82002), the National Natural Science Foundation of China (grant no. 81370165), the Fang Runhua Fund of Hong Kong and the K. C. Wong Magna Fund in Ningbo University.

\section{Availability of data and materials}

The datasets used and/or analyzed during the current study are available from the corresponding author on reasonable request.

\section{Authors' contributions}

SB and WC conceived and designed the study. FH, YW and CL performed the experiments, interpreted the results and wrote the manuscript. SY, YZ and YX analyzed and checked all the data. All authors read and approved the final manuscript and confirm the authenticity of all the raw data.

\section{Ethics approval and consent to participate}

Not applicable.

\section{Patient consent for publication}

Not applicable.

\section{Competing interests}

The authors declare that they have no competing interests.

\section{References}

1. Kitahara CM, Berndt SI, de González AB, Coleman HG, Schoen RE, Hayes RB and Huang WY: Prospective investigation of body mass index, colorectal adenoma, and colorectal cancer in the prostate, lung, colorectal, and ovarian cancer screening trial. J Clin Oncol 31: 2450-2459, 2013.

2. Ji Q, Zhang L, Liu X, Zhou L, Wang W, Han Z, Sui H, Tang Y, Wang Y, Liu N, et al: Long non-coding RNA MALAT1 promotes tumour growth and metastasis in colorectal cancer through binding to SFPQ and releasing oncogene PTBP2 from SFPQ/PTBP2 complex. Br J Cancer 111: 736-748, 2014

3. Pellat A, Deyra J, Coriat R and Chaussade S: Results of the national organised colorectal cancer screening program with FIT in Paris. Sci Rep 8: 4162, 2018.

4. Bhandari A, Woodhouse M and Gupta S: Colorectal cancer is a leading cause of cancer incidence and mortality among adults younger than 50 years in the USA: A SEER-based analysis with comparison to other young-onset cancers. J Investig Med 65: 311-315, 2017

5. Bray F, Ferlay J, Soerjomataram I, Siegel RL, Torre LA and Jemal A: Global cancer statistics 2018: GLOBOCAN estimates of incidence and mortality worldwide for 36 cancers in 185 countries. CA Cancer J Clin 68: 394-424, 2018.

6. Siegel RL, Ward EM and Jemal A: Trends in colorectal cancer incidence rates in the United States by tumor location and stage, 1992-2008. Cancer Epidemiol Biomarkers Prev 21: 411-416, 2012.

7. Souwer ETD, Bastiaannet E, Steyerberg EW, Dekker JT, van den Bos F and Portielje JEA: Risk prediction models for postoperative outcomes of colorectal cancer surgery in the older population-a systematic review. J Geriatr Oncol 11: 1217-1228, 2020.

8. Chakedis J and Schmidt CR: Surgical treatment of metastatic colorectal cancer. Surg Oncol Clin N Am 27: 377-399, 2018.

9. Ueno H, Hase K, Hashiguchi Y, Shinto E, Shimazaki H, Yamamoto J, Nakamura T and Sugihara K: Potential causes of stage migration and their prognostic implications in colon cancer: A nationwide survey of specialist institutions in Japan. Jpn J Clin Oncol 44: 547-555, 2014.

10. Das S, Ciombor KK, Haraldsdottir S and Goldberg RM: Promising new agents for colorectal cancer. Curr Treat Options Oncol 19: 29, 2018.

11. Benzathine Penicillin G: Drugs and Lactation Database (LactMed). National Library of Medicine, Bethesda, MD, 2006.

12. Dalal A, Eskin-Schwartz M, Mimouni D, Ray S, Days W, Hodak E, Leibovici L and Paul M: Interventions for the prevention of recurrent erysipelas and cellulitis. Cochrane Database Syst Rev: Jun 20, 2017 (Epub ahead of print). doi: 10.1002/14651858. CD009758.pub2.

13. Shenoy ES, Macy E, Rowe T and Blumenthal KG: Evaluation and management of penicillin allergy: A review. JAMA 321: 188-199, 2019.

14. Padari H, Metsvaht T, Germovsek E, Barker CI, Kipper K, Herodes K, Standing F, Oselin K, Tasa T, Soeorg H and Lutsar I: Pharmacokinetics of penicillin $\mathrm{G}$ in preterm and term neonates. Antimicrob Agents Chemother 62: e02238-17, 2018.

15. Llor C, Perez A, Carandell E, Garcia-Sangenis A, Rezola J, Llorente $\mathrm{M}$, Gestoso S, Bobé F, Román-Rodríguez $\mathrm{M}$, Cots JM, et al: Efficacy of high doses of penicillin versus amoxicillin in the treatment of uncomplicated community acquired pneumonia in adults. A non-inferiority controlled clinical trial. Aten Primaria 51: 32-39, 2019.

16. Ahlstedt S: Penicillin allergy-can the incidence be reduced? Allergy 39: 151-164, 1984.

17. Suehiro Y, Takemoto Y, Nishimoto A, Ueno K, Shirasawa B, Tanaka T, Kugimiya N, Suga A, Harada E and Hamano K: Dclk1 inhibition cancels 5-FU-induced cell-cycle arrest and decreases cell survival in colorectal cancer. Anticancer Res 38: 6225-6230, 2018.

18. Kee JY,Han YH, Mun JG, Um JY and Hong SH: Pharmacological effect of prohibited combination pair Panax ginseng and Veratrum nigrum on colorectal metastasis in vitro and in vivo. J Ethnopharmacol 220: 177-187, 2018.

19. Jayashankar V, Mueller IA and Rafelski SM: Shaping the multi-scale architecture of mitochondria. Curr Opin Cell Biol 38: 45-51, 2016

20. Roger AJ, Munoz-Gomez SA and Kamikawa R: The origin and diversification of mitochondria. Curr Biol 27: R1177-R1192, 2017. 
21. Vidali S, Aminzadeh S, Lambert B, Rutherford T, Sperl W, Kofler B and Feichtinger RG: Mitochondria: The ketogenic diet-A metabolism-based therapy. Int J Biochem Cell Biol 63: 55-59, 2015.

22. Kalpage HA, Bazylianska V, Recanati MA, Fite A, Liu J Wan J, Mantena N, Malek MH, Podgorski I, Heath EI, et al: Tissue-specific regulation of cytochrome $\mathrm{c}$ by post-translational modifications: Respiration, the mitochondrial membrane potential, ROS, and apoptosis. FASEB J 33: 1540-1553, 2019.

23. Giorgi C, Marchi S, Simoes ICM, Ren Z, Morciano G, Perrone M, Patalas-Krawczyk P, Borchard S, Jędrak P, Pierzynowska K, et al: Mitochondria and reactive oxygen species in aging and age-related diseases. Int Rev Cell Mol Biol 340: 209-344, 2018.

24. Ryter SW, Ma KC and Choi AMK: Carbon monoxide in lung cell physiology and disease. Am J Physiol Cell Physiol 314 C211-C27, 2018

25. Levine B and Klionsky DJ: Development by self-digestion: Molecular mechanisms and biological functions of autophagy. Dev Cell 6: 463-477, 2004.

26. Yun CW and Lee SH: The roles of autophagy in cancer. Int J Mol Sci 19: 3466, 2018.

27. $\mathrm{Xu} \mathrm{HM}$ and $\mathrm{Hu} \mathrm{F}$ : The role of autophagy and mitophagy in cancers. Arch Physiol Biochem 9: 1-9, 2019.

28. Amaravadi R, Kimmelman AC and White E: Recent insights into the function of autophagy in cancer. Genes Dev 30: 1913-1930, 2016

29. Schaaf MB, Keulers TG, Vooijs MA and Rouschop KM: LC3/GABARAP family proteins: Autophagy-(un)related functions. FASEB J 30: 3961-3978, 2016.

30. Zhai Y, Lin P, Feng Z, Lu H, Han Q, Chen J, Zhang Y, He Q, Nan G, Luo X, et al: TNFAIP3-DEPTOR complex regulates inflammasome secretion through autophagy in ankylosing spondylitis monocytes. Autophagy 14: 1629-1643, 2018.

31. Reggiori $\mathrm{F}$ and Ungermann $\mathrm{C}$ : Autophagosome maturation and fusion. J Mol Biol 429: 486-496, 2017.

32. Dekker E, Tanis PJ, Vleugels JLA, Kasi PM and Wallace MB: Colorectal cancer. Lancet 394: 1467-1480, 2019.

33. Klose J, Trefz S, Wagner T, Steffen L, Preissendörfer Charrier A, Radhakrishnan P, Volz C, Schmidt T, Ulrich A, Dieter SM, et al: Salinomycin: Anti-tumor activity in a pre-clinical colorectal cancer model. PLoS One 14: e0211916, 2019.

34. Benzathine Penicillin G: Drugs and Lactation Database [LactMed (Internet)]. National Library of Medicine, Bethesda, MD, 2006. Nov 16, 2020.

35. Alimbetov D, Askarova S, Umbayev B, Davis T and Kipling D: Pharmacological targeting of cell cycle, apoptotic and cell adhesion signaling pathways implicated in chemoresistance of cancer cells. Int J Mol Sci 19: 1690, 2018.

36. Bock FJ and Tait SW: Mitochondria as multifaceted regulators of cell death. Nat Rev Mol Cell Biol 21: 85-100, 2020.

37. Abate M, Festa A, Falco M, Lombardi A, Luce A, Grimaldi A, Zappavigna S, Sperlongano P, Irace C, Caraglia M and Misso G: Mitochondria as playmakers of apoptosis, autophagy and senescence. Semin Cell Dev Biol 98: 139-153, 2020.

38. Pistritto G, Trisciuoglio D, Ceci C, Garufi A and D'Orazi G: Apoptosis as anticancer mechanism: Function and dysfunction of its modulators and targeted therapeutic strategies. Aging 8: 603-619, 2016

39. Gogvadze V, Orrenius S and Zhivotovsky B: Analysis of mitochondrial dysfunction during cell death. Methods Mol Biol 1264: 385-393, 2015.

40. Lawrie TA, Green JT, Beresford M, Wedlake L, Burden S, Davidson SE, Lal S, Henson CC and Andreyev HJ: Interventions to reduce acute and late adverse gastrointestinal effects of pelvic radiotherapy for primary pelvic cancers. Cochrane Database Syst Rev: Jun 23, 2018 (Epub ahead of print). doi: 10.1002/14651858 CD012529.pub2.

41. Burlaka AP, Ganusevich II, Vovk AV, Burlaka AA, Gafurov MR and Lukin SN: Colorectal cancer and mitochondrial dysfunctions of the adjunct adipose tissues: A case study. Biomed Res Int 2018: 2169036, 2018.
42. Akagi J and Baba $\mathrm{H}$ : Hydrogen gas restores exhausted $\mathrm{CD} 8^{+}$ $\mathrm{T}$ cells in patients with advanced colorectal cancer to improve prognosis. Oncol Rep 41: 301-311, 2019.

43. Chimenti MS, Sunzini F, Fiorucci L, Botti E, Fonti GL, Conigliaro P, Triggianese P, Costa L, Caso F, Giunta A, et al: Potential role of cytochrome $\mathrm{c}$ and tryptase in psoriasis and psoriatic arthritis pathogenesis: Focus on resistance to apoptosis and oxidative stress. Front Immunol 9: 2363, 2018.

44. Ai L, Xu A and Xu J: Roles of PD-1/PD-L1 pathway: Signaling, cancer, and beyond. Adv Exp Med Biol 1248: 33-59, 2020.

45. Zhou ZX, Zhao LY, Lin T, Liu H, Deng HJ, Zhu HL, Yan J and Li GX: Long-term oncologic outcomes of laparoscopic vs open surgery for stages II and III rectal cancer: A retrospective cohort study. World J Gastroenterol 21: 5505-5512, 2015.

46. Stolz A, Ernst A and Dikic I: Cargo recognition and trafficking in selective autophagy. Nat Cell Biol 16: 495-501, 2014.

47. Ktistakis NT and Tooze SA: Digesting the expanding mechanisms of autophagy. Trends Cell Biol 26: 624-635, 2016.

48. Heintze J, Costa JR, Weber M and Ketteler R: Ribose 5-phosphate isomerase inhibits LC3 processing and basal autophagy. Cell Signal 28: 1380-1388, 2016.

49. Schlafli AM, Adams O, Galvan JA, Gugger M, Savic S, Bubendorf L, Schmid RA, Becker KF, Tschan MP, Langer R and Berezowska S: Prognostic value of the autophagy markers LC3 and p62/SQSTM1 in early-stage non-small cell lung cancer. Oncotarget 7: 39544-39555, 2016.

50. Dejea CM, Wick EC, Hechenbleikner EM, White JR, Mark Welch JL, Rossetti BJ, Peterson SN, Snesrud EC, Borisy GG, Lazarev M, et al: Microbiota organization is a distinct feature of proximal colorectal cancers. Proc Natl Acad Sci USA 111: 18321-18326, 2014.

51. Tomkovich S, Dejea CM, Winglee K, Drewes JL, Chung L, Housseau F, Pope JL, Gauthier J, Sun X, Mühlbauer M, et al: Human colon mucosal biofilms from healthy or colon cancer hosts are carcinogenic. J Clin Invest 129: 1699-1712, 2019.

52. Tang X, Wang X, Zhao YY, Curtis JM and Brindley DN: Doxycycline attenuates breast cancer-related inflammation by decreasing plasma lysophosphatidate concentrations and inhibiting NF-kappaB activation. Mol Cancer 16: 36, 2017.

53. Sapadin AN and Fleischmajer R: Tetracyclines: Nonantibiotic properties and their clinical implications. J Am Acad Dermatol 54: 258-265, 2006.

54. Zhang J, Haines C, Watson AJM, Hart AR, Platt MJ, Pardoll DM, Cosgrove SE, Gebo KA and Sears CL: Oral antibiotic use and risk of colorectal cancer in the United Kingdom, 1989-2012: A matched case-control study. Gut 68: 1971-1978, 2019.

55. Dejea CM, Fathi P, Craig JM, Boleij A, Taddese R, Geis AL, Wu X, DeStefano Shields CE, Hechenbleikner EM, Huso DL, et al: Patients with familial adenomatous polyposis harbor colonic biofilms containing tumorigenic bacteria. Science 359: 592, 2018.

56. Drewes JL, White JR, Dejea CM, Fathi P, Iyadorai T, Vadivelu J, Roslani AC, Wick EC, Mongodin EF, Loke MF, et al: High-resolution bacterial 16S rRNA gene profile meta-analysis and biofilm status reveal common colorectal cancer consortia. NPJ Biofilms Microbiomes 3: 34, 2017.

57. Dejea CM, Wick EC, Hechenbleikner EM, White JR, Mark Welch JL, Rossetti BJ, Peterson SN, Snesrud EC, Borisy GG, Lazarev M, et al: Microbiota organization is a distinct feature of proximal colorectal cancers. Proc Natl Acad Sci USA 111: 18321-18326, 2014.

This work is licensed under a Creative Commons Attribution-NonCommercial-NoDerivatives 4.0 International (CC BY-NC-ND 4.0) License. 